\title{
Production Systems to Minimize the Latex Harvesting Cost of Rubber (Hevea brasiliensis)
}

\author{
Soumahin Eric Francis \\ Université Jean Lorougnon Guédé, UFR Agroforesterie, \\ Laboratoire de Physiologie et Pathologie Végétale, Daloa, Côte d'Ivoire \\ Adou Bini Yao Christophe
}

Université Nangui Abrogoua, UFR des Sciences de la Nature, Laboratoire de Biologie et Amélioration des Productions Végétales, Abidjan, Côte d'Ivoire Centre Nationale de Recherche Agronomique (CNRA), Programme Hévéa,

Station de Bimbresso, Abidjan, Côte d'Ivoire

\section{Tonessia Dolou Charlotte}

Université Jean Lorougnon Guédé, UFR Agroforesterie,

Laboratoire de Physiologie et Pathologie Végétale, Daloa, Côte d'Ivoire

\section{Obouayeba Samuel}

Centre Nationale de Recherche Agronomique (CNRA), Programme Hévéa, Station de Bimbresso, Abidjan, Côte d'Ivoire

Doi: 10.19044/esj.2018.v14n30p190 URL:http://dx.doi.org/10.19044/esj.2018.v14n30p190

\begin{abstract}
Latex harvesting is the most costly activity in natural rubber production and the shortage of available skill and unstable latex harvester are the main factor affecting in Rubber cultivation and its lead to increase cost of production. Low frequency system (LFT) with the hormonal stimulation is a solution to solve this problem that minimize the cost of latex harvesting. Therefore, a study was conducted for nine years on production systems that minimize the cost of latex harvesting in southwestern Côte d'Ivoire with clones IRCA 130, GT 1 and PB 217 of Hevea brasiliensis. These production systems differ from each other by an increase in tapping frequency, in comparison with the standard tapping (d3) on the above clones in southwestern Côte d'Ivoire. The results indicated that production systems that minimize the cost of latex harvesting admittedly resulted in losses of rubber yield per hectare per year from 1 to $37 \%$, but improved the yield per tree per tapping as well as the productivity of the tapper from 20 to $46 \%$, in year. Moreover, these systems contributed to the improvement of the vegetative growth of trees and kept the rate of dry trees in low level (less than 7\%). Furthermore, these systems also helped to reduce the cost of tapping labor from 1 to $50 \%$, as well as operating costs from 2 to $47 \%$, in comparison with
\end{abstract}


the standard tapping (d3). Finally, in the context of a shortage of tapping labor, these systems help increase the farmer's profit margin from $26 \%$ to $113 \%$, as well as the tapper's income from $26 \%$ to $89 \%$. Therefore, it appears that the use of low frequency harvesting system with the appropriate stimulants appears as a solution to minimize latex harvesting cost and unavailability of harvesters in rubber cultivation.

Keywords: Côte d'Ivoire, cost of harvesting, Hevea brasiliensis, latex harvesting system, profit margin, radial vegetative, reduced tapping frequency, stimulation, rubber production, growth, tapping panel dryness, tapping labor

\section{Introduction}

The conventional latex harvesting system, namely tapping every three days (d3), requires a stable, qualified and large number of tapping labor. This labor is the most significant expenses of latex harvesting. It thus reduces the profit margin of the rubber cultivation. Moreover, the traditional rubber production system limits the exploitation of rubber tree cultivation areas due to lack of tapper (Rodrigo et al., 2003). In addition, the increase in extension of rubber tree cultivation areas will require more tappers. The cost and availability of tappers therefore limit the exploitation of rubber tree cultivation areas as well as rubber production. Two methods can be used to deal with this problem, namely, harvest mechanization and latex harvesting cost reduction (or minimization). Harvest mechanization is a difficult process for the moment. Minimizing the cost of latex harvesting through the development of adequate production systems is the appropriate way to solve this problem. It consists in developing production systems that minimize the cost of latex harvesting by reducing the need for tappers.

The production systems that minimize the cost of latex harvesting are characterized by the reduction in tapping intensity (tapping frequency or tapping cut length) compensated by an increase in hormonal stimulation intensity (stimulation concentration and frequency) (Compagnon, 1986, Soumahin et al., 2009, 2010, 2014). Generally, the reduction in tapping intensity concerns tapping frequency. Indeed, low frequency tapping such as tapping in $\mathrm{d} 4$, d5 and d6 reduce the need for tappers by 25, 37.5 and $50 \%$, respectively (Soumahin, 2010). The production systems that minimize the cost of latex harvesting, namely tapping in $\mathrm{d} 4, \mathrm{~d} 5$ and $\mathrm{d} 6$, enable one tapper to tap more plantation areas than that of the traditional tapping system in $\mathrm{d} 3$. Furthermore, these low frequency tapping systems help reduce the annual consumption of bark and consequently increase the economic lifetime of rubber trees by 10 (d4), 25 (d5) and $48 \%$ (d6) in comparison with the traditional tapping in $\mathrm{d} 3$ (Soumahin, 2010). These systems therefore help 
reduce the need for tappers and the cost of latex harvesting and increase the tapped areas as well as the economic life of rubber tree plantations.

The objective of this study is to assess the incidence of production systems that minimize the cost of latex harvesting on the agronomic parameters and the profitability of rubber trees of three clones. This document provides an update on nine years of experiment on clones IRCA 130, GT 1 and PB 217 in southwestern Côte d'Ivoire.

\section{Materials and methods}

\section{Plant material}

The plant material consisted of Hevea brasiliensis clones IRCA 130, GT 1 and PB 217 belonging to the fast, moderate and slow metabolic activity classes respectively (Chapuset, 2001).

Clone IRCA 130 originates from Côte d'Ivoire. It stems results from the crossing of PB5/51 and IR22. It has an important height growth, a vigor equivalent to that of PB 260 and a very high yield per tree per tapping.

GT 1 is a primary clone originating from Indonesia. It is planted over the rubber growing areas in the world. It has a low growth during tapping, a medium yield per tree per tapping and a low sensitivity to tapping panel dryness and breakage.

Clone PB 217 originates from Malaysia. It resulted from the crossing of PB5/51 with PB6/9. It is one of the best performing clones in Côte d'Ivoire. It has a very good growth during tapping. It has a low sensitivity to tapping panel dryness and breakage.

\section{Methods}

\section{Study environment}

The experiments have been carried out in southwestern Côte d'Ivoire. This part of the country is covered by dense rainforest. Soils are ferrallitic in nature (Kéli et al., 1992, Brou, 2005). The climate of the zone is humid with 4 seasons including 2 dry and 2 rainy seasons. The average annual rainfalls are between 1800 and $2000 \mathrm{~mm}$ with average annual temperatures oscillating between 28.5 and $29^{\circ} \mathrm{C}$. The period of sunshine is estimated at 1500 hours (Brou, 2005).

\section{Experimental design and treatments}

The experimental design was set up in Fisher blocks with 4 treatments and 4 replications at the rate of 100 trees per elementary plot for each clone. Each trial covered an area of 4.7 ha on average. The trees were planted at a density of 510 trees per hectare $(7 \mathrm{~m} \times 2.8 \mathrm{~m})$. The experiment began at the opening of tapping panel and was conducted for 9 years in downward tapping. The half-spiral tapping every four, five and six days ( $\mathrm{S} / 2 \mathrm{~d} 4, \mathrm{~S} / 2 \mathrm{~d} 5, \mathrm{~S} / 2 \mathrm{~d} 6$ ) 
with different stimulation regimes were compared to the half-spiral tapping every three days $(\mathrm{S} / 2 \mathrm{~d} 3$, control). Details of these treatments are given in Table 1.

Table 1. Treatments

\begin{tabular}{|c|c|c|c|c|c|c|c|}
\hline $\mathrm{N}^{\circ}$ & Treatments & $\begin{array}{c}\text { Fast } \\
\text { metabolic } \\
\text { (IRCA 130) }\end{array}$ & $\begin{array}{c}\text { Moderate } \\
\text { metabolic } \\
\text { (GT 1) }\end{array}$ & $\begin{array}{c}\text { Slow } \\
\text { metabolic } \\
\text { (PB 217) }\end{array}$ & $\begin{array}{c}\text { Reduction } \\
\text { in the need } \\
\text { for tappers } \\
(\%)\end{array}$ & $\begin{array}{c}\text { Tapped } \\
\text { areas } \\
\text { (ha) }\end{array}$ & $\begin{array}{l}\text { Extension of } \\
\text { exploitation } \\
\text { life }(\%)\end{array}$ \\
\hline 1 & $\begin{array}{l}\mathrm{S} / 2 \mathrm{~d} 36 \mathrm{~d} / 7 \mathrm{12 \textrm {m } / 1 2} \\
\mathrm{ET} 2.5 \% \mathrm{~Pa} 1(1)(\mathrm{C})\end{array}$ & $4 / y$ & $6 / y$ & $8 / y$ & - & 3 & - \\
\hline 2 & $\begin{array}{l}\mathrm{S} / 2 \mathrm{~d} 46 \mathrm{~d} / 712 \mathrm{~m} / 12 \\
\text { ET2.5\% Pa1(1) }\end{array}$ & $6 / y$ & $8 / y$ & $10 / y$ & 25 & 4 & 10 \\
\hline 3 & $\begin{array}{l}\mathrm{S} / 2 \mathrm{~d} 56 \mathrm{~d} / 7 \mathrm{12 \textrm {m }} / 12 \\
\mathrm{ET} 2.5 \% \mathrm{~Pa} 1(1)\end{array}$ & $8 / y$ & $10 / y$ & $12 / y$ & 37.5 & 5 & 25 \\
\hline 4 & $\begin{array}{l}\mathrm{S} / 2 \mathrm{~d} 66 \mathrm{~d} / 7 \mathrm{12 \textrm {m }} / 12 \\
\text { ET2.5\% Pa1(1) }\end{array}$ & $10 / y$ & $12 / y$ & $14 / y$ & 50 & 6 & 48 \\
\hline
\end{tabular}

$\mathrm{S} / 2$ : half-downward spiral tapping; $\mathrm{d} 3, \mathrm{~d} 4, \mathrm{~d} 5$ and d6: tapped every $3,4,5$ and 6 days; $6 \mathrm{~d} / 7$ : six day in tapping followed by one day; $12 \mathrm{~m} / 12$ : twelve months without repose in year; 4/y, 6/y, 8/y, 10/y, 12/y, and 14/y: 4, 6, 8, 10, 12 and 14 applications of stimulation per year; ET2.5\% Pa1(1): Ethephon of 2.5\% active ingredient with $1 \mathrm{~g}$ of stimulant applied on panel on a $1 \mathrm{~cm}$ band; Pa: tapping panel; $\mathrm{C}$ : control

\section{Tapping}

The latex shaving from the tapping panel was collected in plastic cups using a tapping knife. The rubber tree tapping was carried out 12 months out of 12 (twelve months without repose in year).

\section{Stimulation}

The stimulant was Ethrel. It contains 480 g. . $^{-1}$ of active ingredient (2chloro-ethylphosphonic acid or Ethephon). The stimulating paste was obtained by mixing Ethrel with palm oil so as to get a final concentration of $2.5 \%$ active ingredient. It was applied to $1 \mathrm{~cm}$ strip of the regeneration panel (Pa) by using a brush. The stimulations were applied throughout the year except the periods of defoliation and refoliation (from January to March).

\section{Measurements made}

\section{Rubber yield}

Rubber yield was recorded monthly for each treatment. Dry rubber yield was expressed in kilograms per hectare $(\mathrm{kg} / \mathrm{ha})$ and in grams per tree per tapping $(\mathrm{g} / \mathrm{t} / \mathrm{t})$.

\section{Productivity of the tapper}

The productivity of the tapper was expressed in $\mathrm{kg} / \mathrm{tapper} / \mathrm{day}(\mathrm{kg} / \mathrm{t} / \mathrm{d})$. 


\section{Girth increment}

The trunk circumference at $1.70 \mathrm{~m}$ from the ground was measured on each treated tree, using a measuring tape, at the beginning and at the end of the experiment. The average annual increment of trunk circumference (cm/year) after nine years of experimentation was determined by the following relation:

$$
\text { Acc }=\left(\operatorname{Circf}_{-}-\operatorname{Circ}_{i}\right) / \mathbf{i}
$$

Acc: annual girth increment; Circs: circumference of trees at the end of experimentation; Circi: initial circumference of the trees at the beginning of the experiment; $\mathbf{i}$ : number of years of the experiment

\section{Tapping panel dryness}

The method of rapid tapping panel dryness survey by visual estimation (Van De Sype, 1984) made it possible to account for the rate of tapping panel dryness from the allocation of a number between 0 and 6 in proportion to the length of taping panel dryness. On that respect, the trees tapped were rated from 0 to 6 in proportion to the progress of the disease according to the code " 0 " (healthy cut, normal flow all along the tapping cut) and " 6 " (completely dry cut). For each plot, the accurate count of the condition of the trees was performed and the percentage of total sick tapping panel length (LEM\%) was calculated as follows:

$$
\operatorname{LEM}(\%)=100 \times\left(0 n_{0}+0,1 n_{1}+0,3 n_{2}+0,5 n_{3}+0,7 n_{4}+0,9 n_{5}+n_{6}+E S\right) / N
$$

$0 ; 0,1 ; 0,3 ; 0,5 ; 0,7 ; 0,9$ and 1 : coefficient expressing the average percentage of sick tapping panel of the class considered (score awarded); ni: number of trees per tapping panel dryness class; N: total number of trees per plot; ES: number of trees for which tapping has already been stopped due to total tapping panel dryness.

\section{Economic calculations}

For each system applied to the trees, the following parameters have been calculated and expressed in United State Dollars (USD):

- Cost of stimulation (CS)

- Cost of tapping labor (CTL)

- Operating expenses (OE): CS + CTL

- Operating revenue (OR): Y x $\mathrm{P}$

- Farmer's profit margin: OR - OE

- Tapper's income

With - Y: Rubber yield (kg)

- P: Rubber selling price

The methods of payment of the selected tappers were performancebased pay and workday-based pay. For performance-based pay, the cost of tapping labor was 0.1 USD per kilogram of rubber yielded. For workday-based pay, the cost was 5 USD per day. 
The cost of one liter of Ehtrel was 20 USD. That of palm oil of one liter was 3 USD. The farm gate selling price of the $\mathrm{kg}$ of rubber was 0.6 USD.

The tapping task was set at 1 ha per tapper and per day, that is, 400 trees per day.

\section{Statistical analyses}

The collected data were subjected to an analysis of variance using the statistical software XLSTAT version 7.5.3. The level of significance of differences between the averages of data was estimated by the Newman-Keuls test at $5 \%$ threshold.

\section{Results}

\section{Rubber yield of rubber trees $(\mathrm{kg} / \mathrm{ha} / \mathrm{y})$}

For each clone, the rubber yield in gram per tree per tapping $(\mathrm{g} / \mathrm{t} / \mathrm{t})$ significantly $(\mathrm{P}<0.05)$ increased with a reduction in tapping frequency, while the yields in kilogram per hectare per year $(\mathrm{kg} / \mathrm{ha} / \mathrm{y})$ significantly $(\mathrm{P}<0.05)$ decreased with a reduction in tapping frequency (Tables 2, 3 and 4). In clone IRCA 130, the rubber yield losses $(\mathrm{kg} / \mathrm{ha} / \mathrm{y})$ caused by the reduction in tapping frequencies, compared to the control, were 1, 3 and $6 \%$ for the tapping in $\mathrm{d} 4$, d5 and d6, respectively. In GT 1, these losses were 6, 10 and 24\%, whereas in PB 217 they were 8, 16 and $27 \%$.

Table 2. Rubber yield (g/t/t and kg/ha/year) of clone IRCA 130 for nine years in the southwest of Côte d'Ivoire

\begin{tabular}{llll}
\hline Treatments & $\mathrm{g} / \mathrm{t} / \mathrm{t}$ & $\mathrm{kg} / \mathrm{ha} / \mathrm{year}$ & Loss (\% C) \\
\hline 1. S/2 d3 6d/7 ET2.5\% Pa1(1) 4/y (C) & $\mathbf{5 3 ~ d}$ & $\mathbf{2 . 3 5 7} \mathbf{a}$ & - \\
2. S/2 d4 6d/7 ET2.5\% Pa 1(1) 6/y & $69 \mathrm{c}$ & $2.334 \mathrm{a}$ & -1 \\
3. S/2 d5 6d/7 ET2.5\% Pa1(1) 8/y & $81 \mathrm{~b}$ & $2.280 \mathrm{~b}$ & -3 \\
4. S/2 d6 6d/7 ET2.5\% Pa1(1) 10/y & $98 \mathrm{a}$ & $2.230 \mathrm{~b}$ & -6 \\
\hline
\end{tabular}

Mean within columns followed by the same letters are not significantly different from each other $(\mathrm{P}<0.05)$.

Loss \% $\mathrm{C}$ : loss in comparison with the control

Table 3. Rubber yield (g/t/t and kg/ha/year) of clone GT 1 for nine years in the south-west of Côte d'Ivoire

\begin{tabular}{llll}
\hline Treatments & $\mathrm{g} / \mathrm{t} / \mathrm{t}$ & $\mathrm{kg} / \mathrm{ha} / \mathrm{year}$ & Loss (\% C) \\
\hline 1. S/2 d3 6d/7 ET2.5\% Pa1(1) 6/y (C) & $\mathbf{4 4} \mathbf{d}$ & $\mathbf{2 . 1 1 5} \mathbf{a}$ & - \\
2. S/2 d4 6d/7 ET2.5\% Pa1(1) 8/y & $55 \mathrm{c}$ & $1.996 \mathrm{ab}$ & -6 \\
3. S/2 d5 6d/7 ET2.5\% Pa1(1) 10/y & $63 \mathrm{~b}$ & $1.918 \mathrm{~b}$ & -10 \\
4. S/2 d6 6d/7 ET2.5\% Pa1(1) 12/y & $70 \mathrm{a}$ & $1.700 \mathrm{c}$ & -24 \\
\hline
\end{tabular}

Mean within columns followed by the same letters are not significantly different from each other $(\mathrm{P}<0.05)$.

Loss $\% \mathrm{C}$ : loss in comparison with the control 
Table 4. Rubber yield ( $\mathrm{g} / \mathrm{t} / \mathrm{t}$ and $\mathrm{kg} / \mathrm{ha} / \mathrm{year}$ ) of clone PB 217, for nine years in the southwest of Côte d'Ivoire

\begin{tabular}{llll}
\hline Treatments & $\mathrm{g} / \mathrm{t} / \mathrm{t}$ & $\mathrm{kg} / \mathrm{ha} / \mathrm{year}$ & Loss $(\% \mathrm{C})$ \\
\hline 1. S/2 d3 6d/7 ET2.5\% Pa1(1) 8/y (C) & $\mathbf{4 6} \mathbf{d}$ & $\mathbf{2 . 1 2 9} \mathbf{a}$ & - \\
2. S/2 d4 6d/7 ET2.5\% Pa1(1) 10/y & $59 \mathrm{c}$ & $1.970 \mathrm{ab}$ & -8 \\
3. S/2 d5 6d/7 ET2.5\% Pa1(1) 12/y & $65 \mathrm{~b}$ & $1.780 \mathrm{~b}$ & -16 \\
4. S/2 d6 6d/7 ET2.5\% Pa1(1) 14/y & $72 \mathrm{a}$ & $1.550 \mathrm{c}$ & -27 \\
\hline
\end{tabular}

Mean within columns followed by the same letters are not significantly different from each other $(\mathrm{P}<0.05)$.

Loss \% $\mathrm{C}$ : loss in comparison with the control

\section{Tapper productivity $(\mathrm{kg} / \mathrm{t} / \mathrm{d})$}

The daily productivity of the tapper in dry rubber increased significantly $(\mathrm{P}<0.05)$ with the reduction in tapping frequency regardless of the clone tested (Table 5). Productivity gains due to the reduction in tapping frequencies, compared to the conventional tapping, varied from 33 to $86 \%$, from 22 to $56 \%$, and from 33 to $61 \%$, respectively in clones IRCA 130, GT 1 and PB 217.

Table 5: Tapper productivity ( $\mathrm{kg} / \mathrm{t} / \mathrm{d})$ of clones IRCA 130, GT 1 and PB 217, for nine years in the south-west of Côte d'Ivoire

\begin{tabular}{|c|c|c|c|c|c|c|}
\hline Treatments & IRCA 130 & $\begin{array}{l}\text { Gain } \\
(\% \mathrm{C})\end{array}$ & GT 1 & $\begin{array}{l}\text { Gain } \\
(\% \mathrm{C})\end{array}$ & PB 217 & $\begin{array}{l}\text { Gain } \\
(\% \mathrm{C})\end{array}$ \\
\hline 1. S/2 d3 6d/7 ET2.5\% (C) & 21d & - & $18 \mathrm{~d}$ & - & $18 \mathrm{~d}$ & - \\
\hline 2. $\mathrm{S} / 2 \mathrm{~d} 4 \mathrm{6d} / 7 \mathrm{ET} 2.5 \%$ & $28 \mathrm{c}$ & 33 & $22 \mathrm{c}$ & 22 & $24 \mathrm{c}$ & 33 \\
\hline 3. S/2 d5 6d/7 ET2.5\% & $32 b$ & 52 & $25 b$ & 39 & $26 b$ & 44 \\
\hline 4. $\mathrm{S} / 2 \mathrm{~d} 6 \mathrm{6d} / 7 \mathrm{ET} 2.5 \%$ & $39 \mathrm{a}$ & 86 & $28 \mathrm{a}$ & 56 & $29 \mathrm{a}$ & 61 \\
\hline
\end{tabular}

Mean within columns followed by the same letters are not significantly different from each other $(\mathrm{P}<0.05)$.

Gain \%C: gain in comparison with the control

\section{Radial vegetative growth of rubber trees (cm/year)}

Production systems that minimize the cost of latex harvesting induced a significant higher girth increment than that of the conventional tapping system tapping every three days in PB 217 (Table 6). In clones IRCA 130 and PB 217, did not show any significant girth increment with respect to all treatments.

Table 6. Girth increment (cm/y) of clones IRCA 130, GT 1 and PB 217, for nine years in the south-west of Côte d'Ivoire

\begin{tabular}{lllc}
\hline Treatments & IRCA 130 & GT 1 & PB 217 \\
\hline 1. S/2 d3 6d/7 ET2.5\% (C) & $\mathbf{2 . 7}$ a & $1.8 \mathrm{a}$ & $2.8 \mathrm{c}$ \\
2. S/2 d4 6d/7 ET2.5\% & $2.7 \mathrm{a}$ & $1.8 \mathrm{a}$ & $3.1 \mathrm{abc}$ \\
3. S/2 d5 6d/7 ET2.5\% & $2.7 \mathrm{a}$ & $1.9 \mathrm{a}$ & $3.2 \mathrm{bc}$ \\
4. S/2 d6 6d/7 ET2.5\% & $2.6 \mathrm{a}$ & $2.0 \mathrm{a}$ & $3.3 \mathrm{a}$ \\
\hline
\end{tabular}

Mean within columns followed by the same letters are not significantly different from each other $(\mathrm{P}<0.05)$. 


\section{Sensitivity to tapping panel dryness of rubber trees}

The rates of dry trees were low (less than 7\%) and of the same order of magnitude for all clones (Table 7).

Table 7: Tapping panel dryness rates (\%) of trees in clones IRCA 130, GT 1 and PB 217, for nine years in the south-west of Côte d'Ivoire

\begin{tabular}{llll}
\hline Treatments & IRCA 130 & GT 1 & PB 217 \\
\hline 1. S/2 d3 6d/7 ET2.5\% (C) & $\mathbf{2 . 2}$ & 3.0 & 2.8 \\
2. S/2 d4 6d/7 ET2.5\% & 1.8 & 6.3 & 3.4 \\
3. S/2 d5 6d/7 ET2.5\% & 2.3 & 3.5 & 4.0 \\
4. S/2 d6 6d/7 ET2.5\% & 1.3 & 4.1 & 3.0
\end{tabular}

\section{Economic calculations}

\section{Cost of stimulation}

The costs of stimulation of the reduced tapping frequency patterns were higher than those of the conventional tapping in $\mathrm{d} 3$, whatever the clone in whole experimental period (Table 8).

Table 8. Annual cost (USD) of the stimulation of clones IRCA 130, GT 1 and PB 217, for nine years in the south-west of Côte d'Ivoire

\begin{tabular}{lllllll}
\hline Treatments & $\begin{array}{l}\text { IRCA } \\
\mathbf{1 3 0}\end{array}$ & $\begin{array}{l}\text { Gain } \\
(\% \mathbf{C})\end{array}$ & GT 1 & $\begin{array}{l}\text { Gain } \\
(\% \mathbf{C})\end{array}$ & PB 217 & $\begin{array}{l}\text { Gain } \\
(\% \mathbf{C})\end{array}$ \\
\hline 1. S/2 d3 6d/7 ET2.5\% (C) & $\mathbf{6 . 7}$ & - & 10.0 & - & 13.7 & - \\
2. S/2 d4 6d/7 ET2.5\% & 10.0 & 50 & 13.3 & 33 & 16.7 & 25 \\
3. S/2 d5 6d/7 ET2.5\% & 13.3 & 100 & 16.7 & 67 & 20.0 & 50 \\
4. S/2 d6 6d/7 ET2.5\% & 16.7 & 150 & 20.0 & 100 & 23.3 & 75 \\
\hline
\end{tabular}

Gain \%C: gain in comparison with the control

\section{Cost of tapping labor}

Cost of tapping labor was higher in conventional tapping (d3) than in reduced frequency of tapping irrespective of clone and tapper payment methods (Tables 9 and 10). The cost of tapping labor was higher in workdaybased pay than in performance-based pay, especially in clone PB 217 in average of overall treatments. In clone IRCA 130, more productive, the cost of tapping labor was higher in performance-based pay in average of overall treatments.

In the case of labor performance-based pay, the reduced tapping frequency treatments induced a reduction in labor costs ranging from 1 to $27 \%$, in comparison with the conventional tapping (d3). In tapper workday-based pay, the patterns with reduced tapping frequency caused a reduction in the cost of labor varying from 25 to $50 \%$, in comparison with the conventional tapping (3). The reduction in the cost of tapper was more substantial in workday-based pay than in performance-based pay. 
Table 9. Annual cost (USD) of the tapping labor in performance-based pay in IRCA 130, GT1 and PB 217 clones, for nine years in the south-west of Côte d'Ivoire

\begin{tabular}{lcccccc}
\hline \multicolumn{1}{c}{ Treatments } & $\begin{array}{c}\text { IRCA } \\
\mathbf{1 3 0}\end{array}$ & $\begin{array}{c}\text { Decrease } \\
(\boldsymbol{\%} \text { C) }\end{array}$ & GT 1 & $\begin{array}{c}\text { Decrease } \\
(\% \mathbf{C})\end{array}$ & PB 217 & $\begin{array}{c}\text { Decrease } \\
(\% \mathbf{C})\end{array}$ \\
\hline 1. S/2 d3 6d/7 ET2.5\% (C) & $\mathbf{3 9 2}$ & - & $\mathbf{3 5 3}$ & - & $\mathbf{3 5 5}$ & - \\
2. S/2 d4 6d/7 ET2.5\% & 389 & -1 & 333 & -6 & 328 & -7 \\
3. S/2 d5 6d/7 ET2.5\% & 380 & -3 & 320 & -9 & 297 & -16 \\
4. S/2 d6 6d/7 ET2.5\% & 372 & -5 & 283 & -20 & 258 & -27 \\
\hline
\end{tabular}

NB : Tapped area : 1 ha (400 trees) ; cost of tapping labor: 0.1 USD per kilogram of rubber yielded.

Table 10. Annual cost (USD) of the tapping labor in workday-based pay in IRCA 130, GT 1 and PB 217 clones, for nine years in the south-west of Côte d'Ivoire

\begin{tabular}{lcccccc}
\hline \multicolumn{1}{c}{ Treatments } & $\begin{array}{c}\text { IRCA } \\
\mathbf{1 3 0}\end{array}$ & $\begin{array}{c}\text { Decrease } \\
(\boldsymbol{\%} \text { C })\end{array}$ & GT 1 & $\begin{array}{c}\text { Decrease } \\
(\boldsymbol{\%} \text { C })\end{array}$ & $\begin{array}{c}\text { PB } \\
\mathbf{2 1 7}\end{array}$ & $\begin{array}{c}\text { Decrease } \\
(\boldsymbol{\%} \text { C })\end{array}$ \\
\hline $\mathbf{1 . S}$ /2 d3 6d/7 ET2.5\% (C) & $\mathbf{5 2 0}$ & - & $\mathbf{5 2 0}$ & - & $\mathbf{5 2 0}$ & - \\
2. S/2 d4 6d/7 ET2.5\% & 390 & -25 & 390 & -25 & 390 & -25 \\
3. S/2 d5 6d/7 ET2.5\% & 315 & -39 & 315 & -39 & 315 & -39 \\
4. S/2 d6 6d/7 ET2.5\% & 260 & -50 & 260 & -50 & 260 & -50 \\
\hline
\end{tabular}

NB : Tapped area: 1 ha (400 trees) ; cost of tapping labor: 5 USD per day.

\section{Operating expenses}

The operating expenses (cost of stimulation and cost of tapping labor) were higher in conventional tapping (d3) and decreased with the reduction in tapping frequency irrespective of the clone and labor payment methods (Tables 11 and 12).

With regard to tapping labor performance-based pay, the reduction in tapping frequency induced a reduction in operating expenses from 2 to $23 \%$, in comparison with the conventional tapping (3). In a workday-based pay context, the reasons for reduced tapping frequency resulted in a decrease in operating costs from 24 to $47 \%$, regardless of the clone. The decrease in operating expenses was more substantial in a workday-based pay.

Table 11. Annual operating expenses (USD) of one hectare of clones IRCA 130, GT 1 and PB 217 plantations and for tapper performance-based pay, for nine years in the south-west of Côte d'Ivoire

\begin{tabular}{lcccccc}
\hline \multicolumn{1}{c}{ Treatments } & $\begin{array}{c}\text { IRCA } \\
\mathbf{1 3 0}\end{array}$ & $\begin{array}{c}\text { Decrease } \\
(\boldsymbol{\%} \text { C) }\end{array}$ & GT 1 & $\begin{array}{c}\text { Decrease } \\
(\% \mathbf{C})\end{array}$ & $\begin{array}{c}\text { PB } \\
\mathbf{2 1 7}\end{array}$ & $\begin{array}{c}\text { Decrease } \\
(\boldsymbol{\%} \text { C) }\end{array}$ \\
\hline 1. S/2 d3 6d/7 ET2.5\% (C) & $\mathbf{4 0 0}$ & - & $\mathbf{3 6 3}$ & - & $\mathbf{3 6 8}$ & - \\
2. S/2 d4 6d/7 ET2.5\% & 399 & 0 & 346 & -5 & 345 & -6 \\
3. S/2 d5 6d/7 ET2.5\% & 393 & -2 & 336 & -7 & 317 & -14 \\
4. S/2 d6 6d/7 ET2.5\% & 388 & -3 & 303 & -16 & 282 & -23 \\
\hline
\end{tabular}

NB : Tapped area : 1 ha (400 trees) ; cost of tapping labor: 0.1 USD per kilogram of rubber yielded. 
Table 12. Annual operating expenses (USD) of one hectare of clones IRCA 130, GT 1 and PB 217 plantations and for tapper workday-based pay, for nine years in the south-west of Côte d'Ivoire

\begin{tabular}{lcccccc}
\hline \multicolumn{1}{c}{ Treatments } & $\begin{array}{c}\text { IRCA } \\
\mathbf{1 3 0}\end{array}$ & $\begin{array}{c}\text { Decrease } \\
(\boldsymbol{\%} \text { C) }\end{array}$ & GT 1 & $\begin{array}{c}\text { Decrease } \\
(\boldsymbol{\%} \text { C })\end{array}$ & $\begin{array}{c}\text { PB } \\
\mathbf{2 1 7}\end{array}$ & $\begin{array}{c}\text { Decrease } \\
(\boldsymbol{\%} \text { C) }\end{array}$ \\
\hline 1. S/2 d3 6d/7 ET2.5\% (C) & $\mathbf{5 2 6}$ & & $\mathbf{5 3 0}$ & & $\mathbf{5 3 3}$ & \\
2. S/2 d4 6d/7 ET2.5\% & 400 & -24 & 403 & -24 & 407 & -24 \\
3. S/2 d5 6d/7 ET2.5\% & 328 & -38 & 332 & -37 & 335 & -37 \\
4. S/2 d6 6d/7 ET2.5\% & 277 & -47 & 280 & -47 & 283 & -47 \\
\hline
\end{tabular}

NB : Tapped area: 1 ha (400 trees) ; cost of tapping labor: 5 USD per day.

\section{Farmer's profit margins}

\section{In a normal context of tapping labor availability}

In a tapper performance-based pay, the conventional tapping (d3) system recorded the highest profit margin (Table 13) and decreased with the reduction in tapping frequency. The loss of profit margins caused by the reduced tapping frequency patterns were from 1 to $6 \%$ in clone IRCA 130, from 6 to $20 \%$ in clone GT 1 and from 8 to $28 \%$ in clone PB 217.

In the context of workday-based pay, low tapping frequency production systems recorded the highest profit margins, particularly in clone IRCA 130 (Table 14). These profit margins, from 6 to 7\%, were higher than those of the conventional tapping. The profit margin in $\mathrm{d} 4$ and $\mathrm{d} 5$ systems in clone GT 1, were identical to those of the conventional tapping, while tapping in $\mathrm{d} 6$ system resulted in a loss of profit margins by $10 \%$. In PB 217, production systems of from $\mathrm{d} 4$ to $\mathrm{d} 6$, reduce the cost of latex harvesting induced profit margins from 2 to $21 \%$.

Table 13. Farmer's profit margins (USD) for one ha of plantation of clones IRCA 130, GT 1 and PB 217 and for tapper performance-based pay, for nine years in the south-west of Côte d'Ivoire

\begin{tabular}{lllllll}
\hline Treatments & $\begin{array}{l}\text { IRCA } \\
\mathbf{1 3 0}\end{array}$ & $\begin{array}{l}\text { Decrease } \\
(\% \mathbf{C})\end{array}$ & GT 1 & $\begin{array}{l}\text { Decrease } \\
(\% \mathbf{C})\end{array}$ & PB 217 & $\begin{array}{l}\text { Decrease } \\
(\% \mathbf{C})\end{array}$ \\
\hline 1. S/2 d3 6d/7 ET2.5\% (C) & 1.958 & - & 1.753 & - & 1.761 & \\
2. S/2 d4 6d/7 ET2.5\% & 1.935 & -1 & 1.650 & -6 & 1.625 & -8 \\
3. S/2 d5 6d/7 ET2.5\% & 1.887 & -4 & 1.582 & -10 & 1.463 & -17 \\
4. S/2 d6 6d/7 ET2.5\% & 1.842 & -6 & 1.397 & -20 & 1.268 & -28 \\
\hline
\end{tabular}

NB : Tapped area : 1 ha (400 trees) ; cost of tapping labor: 0.1 USD per kilogram of rubber yielded; selling price of the kg of rubber : 0.6 USD. 
Table 14. Farmer's profit margins (USD) for one ha of plantation of clones IRCA 130, GT 1 and PB 217 and for tapper workday-based pay, for nine years in the south-west of Côte d'Ivoire

\begin{tabular}{lllllll}
\hline Treatments & $\begin{array}{l}\text { IRCA } \\
\mathbf{1 3 0}\end{array}$ & $\begin{array}{l}\text { Increase } \\
(\% \mathbf{C})\end{array}$ & GT 1 & $\begin{array}{l}\text { Decrease } \\
(\% \mathbf{C})\end{array}$ & PB 217 & $\begin{array}{l}\text { Decrease } \\
(\% \mathrm{C})\end{array}$ \\
\hline 1. S/2 d3 6d/7 ET2.5\% (C) & 1.830 & - & 1.585 & - & 1.596 & \\
2. S/2 d4 6d/7 ET2.5\% & 1.934 & 6 & 1.593 & 0 & 1.563 & -2 \\
3. S/2 d5 6d/7 ET2.5\% & 1.952 & 7 & 1.586 & 0 & 1.445 & -9 \\
4. S/2 d6 6d/7 ET2.5\% & 1.953 & 7 & 1.420 & -10 & 1.267 & -21 \\
\hline
\end{tabular}

NB : Tapped area: 1 ha (400 trees) ; cost of tapping labor: 5 USD per day; selling price of the $\mathrm{kg}$ of rubber : $0.6 \mathrm{USD}$.

\section{$\underline{\text { In a context of labor shortage }}$}

All reduced tapping frequency patterns gave higher profit margins than the conventional tapping in $\mathrm{d} 3$ irrespective of the clone (Tables 15 and 16).

With regard to the tapping labor performance-based pay, profit margins gains were between 32 and 88\% for clone IRCA 130, 26 and $59 \%$ for GT 1 and 23 and 44\% for PB 217. In the context of workday-based pay, profit margins gains varied from 41 to $113 \%$ in clone IRCA 130, from 34 to 79\% in GT 1 and from 31 to 59\% in PB 217.

Table 15. Farmer's profit margins (USD) for 6 ha plantation of clones IRCA 130, GT 1 and PB 217 and for tapper performance-based pay in a context of labor shortage, for nine years in the south-west of Côte d'Ivoire

\begin{tabular}{lllllll}
\hline Treatments & IRCA 130 & $\begin{array}{l}\text { Increase } \\
(\boldsymbol{\%} \text { C) }\end{array}$ & GT 1 & $\begin{array}{l}\text { Increase } \\
(\boldsymbol{\%} \text { C })\end{array}$ & PB 217 & $\begin{array}{l}\text { Increase } \\
(\boldsymbol{\%} \text { C })\end{array}$ \\
\hline 1. S/2 d3 6d/7 ET2.5\% (C) & $\mathbf{5 . 8 7 3}$ & - & $\mathbf{5 . 2 5 8}$ & - & $\mathbf{5 . 2 8 3}$ & - \\
2. S/2 d4 6d/7 ET2.5\% & 7.740 & 32 & 6.600 & 26 & 6.500 & 23 \\
3. S/2 d5 6d/7 ET2.5\% & 9.433 & 61 & 7.908 & 50 & 7.317 & 39 \\
4. S/2 d6 6d/7 ET2.5\% & 11.050 & 88 & 8.380 & 59 & 7.610 & 44 \\
\hline
\end{tabular}

NB : Cost of tapping labor: 0.1 USD per kilogram of rubber yielded; selling price of the $\mathrm{kg}$ of rubber : 0.6 USD.

Table 16. Farmer's profit margins (USD) for 6 ha plantation of clones IRCA 130, GT 1 and

PB 217 and for tapper workday-based pay in a context of labor shortage, for nine years in the south-west of Côte d'Ivoire

\begin{tabular}{lllllll}
\hline Treatments & IRCA 130 & $\begin{array}{l}\text { Increase } \\
(\% \mathbf{C})\end{array}$ & GT 1 & $\begin{array}{l}\text { Increase } \\
(\boldsymbol{\%} \text { C) }\end{array}$ & PB 217 & $\begin{array}{l}\text { Increase } \\
(\boldsymbol{\%} \text { C) }\end{array}$ \\
\hline 1. S/2 d3 6d/7 ET2.5\% (C) & $\mathbf{5 . 4 9 1}$ & - & $\mathbf{4 . 7 5 5}$ & - & $\mathbf{4 . 7 8 7}$ & - \\
2. S/2 d4 6d/7 ET2.5\% & 7.736 & 41 & 6.371 & 34 & 6.253 & 31 \\
3. S/2 d5 6d/7 ET2.5\% & 9.758 & 78 & 7.932 & 67 & 7.225 & 51 \\
4. S/2 d6 6d/7 ET2.5\% & 11.720 & 113 & 8.520 & 79 & 7.600 & 59 \\
\hline
\end{tabular}

NB : Cost of tapping labor: 5 USD per day; selling price of the kg of rubber : 0.6 USD.

\section{Tapper's income}

When the tapper was paid according to performance, production systems that minimize the cost of latex harvesting gave higher incomes than 
those of the conventional system, regardless of the clone (Table 17). Therefore, these results indicate that the tapper's income increased with the reduction in tapping frequency. Further it is showed that the tappers' income gains increased from 32 to $89 \%$ in clone IRCA 130, from 26 to $61 \%$ in clone GT 1 and from 23 to $46 \%$ in clone PB 217.

When the tapper was paid according to workday, his income remained fixed. It was 1565 USD for the 313 workdays of the year (Table 18).

Table 17. Revenue (USD) of the tapper for 6 ha plantation of clones IRCA 130, GT 1 and PB 217 and for tapper performance-based pay in a context of labor shortage for nine years in the south-west of Côte d'Ivoire

\begin{tabular}{lllllll}
\hline Treatments & IRCA 130 & $\begin{array}{l}\text { Increase } \\
(\% \mathbf{C})\end{array}$ & GT 1 & $\begin{array}{l}\text { Increase } \\
(\% \mathbf{C})\end{array}$ & PB 217 & $\begin{array}{l}\text { Increase } \\
(\% \mathbf{C})\end{array}$ \\
\hline 1. S/2 d3 6d/7 ET2.5\% (C) & $\mathbf{1 . 1 7 9}$ & - & $\mathbf{1 . 0 5 8}$ & & $\mathbf{1 . 0 6 5}$ & \\
2. S/2 d4 6d/7 ET2.5\% & 1.556 & 32 & 1.331 & 26 & 1.313 & 23 \\
3. S/2 d5 6d/7 ET2.5\% & 1.900 & 61 & 1.098 & 51 & 1.483 & 39 \\
4. S/2 d6 6d/7 ET2.5\% & 2.230 & 89 & 1.700 & 61 & 1.550 & 46 \\
\hline
\end{tabular}

NB : Cost of tapping labor: 0.1 USD per kilogram of rubber yielded; selling price of the $\mathrm{kg}$ of rubber : 0.6 USD.

Table 18. Revenue (USD) of the tapper for 6 ha plantation of clones IRCA 130, GT 1 and PB 217 and for tapper workday-based pay in a context of labor shortage for nine years in the south-west of Côte d'Ivoire

\begin{tabular}{lllllll}
\hline Treatments & IRCA 130 & $\begin{array}{l}\text { Increase } \\
(\boldsymbol{\%} \text { C) }\end{array}$ & GT 1 & $\begin{array}{l}\text { Increase } \\
(\% \mathbf{\%})\end{array}$ & PB 217 & $\begin{array}{l}\text { Increase } \\
(\boldsymbol{\%} \text { C) }\end{array}$ \\
\hline 1. S/2 d3 6d/7 ET2.5\% (C) & $\mathbf{1 . 5 6 5}$ & & $\mathbf{1 . 5 6 5}$ & & $\mathbf{1 . 5 6 5}$ & \\
2. S/2 d4 6d/7 ET2.5\% & 1,565 & 0 & 1.565 & 0 & 1.565 & 0 \\
3. S/2 d5 6d/7 ET2.5\% & 1.565 & 0 & 1.565 & 0 & 1.565 & 0 \\
4. S/2 d6 6d/7 ET2.5\% & 1.565 & 0 & 1.565 & 0 & 1.565 & 0 \\
\hline
\end{tabular}

NB : Cost of tapping labor: 5 USD per day; selling price of the kg of rubber : 0.6 USD.

\section{Discussion \\ Rubber yield}

Reduced tapping frequency treatments gave yields in $\mathrm{g} / \mathrm{t} / \mathrm{t}$ higher than that of the conventional system. Indeed, the yield in $\mathrm{g} / \mathrm{t} / \mathrm{t}$ was improved when the time between two consecutive tapping was extended (Compagnon, 1986; Soumahin, 2010). However, low frequency tapping systems showed low annual average yields $(\mathrm{kg} / \mathrm{ha})$, in comparison with the conventional tapping (every three days). This is explained by the fact that the more times the rubber tree is tapped, the more in situ regeneration of latex is important (Obouayeba and Boa, 1993). Indeed, the tapping, by the stress that it induces, activates the metabolism of the laticiferous in the same way as the hormonal stimulation, by ethylene production (Chrestin, 1985; Atsin et al., 2016). 


\section{Daily performance of the tapper}

Reduced tapping frequency systems have helped increase the performance of the tapper compared to that of the control system. This is explained by the fact that, in reduced tapping frequency, the rubber yield per tree and per tapping is improved. These results are supported with the finding of Soumahin (2010).

\section{Vegetative growth}

The trees under reduced tapping frequency showed girth increment $(\mathrm{cm} / \mathrm{y})$ slightly higher than those of the control system (tapping in $\mathrm{d} 3$ ). The decrease in tapping frequency caused an increase in girth increment (Soumahin et al., 2009, 2014). Growth potential being negatively correlated with rubber yield (Gohet et al., 1996), the depressive impact of yield on growth would be important especially as the yield potential is high and vice versa (Obouayeba et al., 2002). Indeed, there was a strong competition for photosynthetic assimilates between vegetative growth and rubber yield (Templeton, 1969). Thus, for the trees tapped at reduced frequency, photosynthetic assimilates were, because of the long time period between two consecutive tapping, more sufficient to ensure rubber yield and vegetative growth, hence the higher girth increment observed in the latter.

\section{Tapping panel dryness}

The rates of tapping panel dryness of trees of production systems minimizing the cost of harvesting were overall higher than those of the control trees. These results are not in line with those of Chrestin (1985), which showed that the rate of tapping panel dryness increases with the frequency of tapping.This is why, according to De Fay (1981), the causes of the syndrome of tapping panel dryness show ambiguities.

\section{Economic calculations}

The costs of stimulation of low tapping frequency systems that were higher than that of the conventional tapping (d3) are due to more of applications (Soumahin, 2010 ; Soumahin et al, 2010).

The lower tapping labor costs observed in the production systems that minimize the cost of latex harvesting, whatever the tapper payment method, can be explained by the fact that low frequency tapping systems are less productive and less frequently tapped (Soumahin, 2010 ; Soumahin et al, 2010).

Production systems to minimize the cost of latex harvesting resulted in operating costs lower than that of the conventional system. Indeed, the higher cost of stimulation in low tapping frequency production systems accounted for less than $10 \%$ of the operating costs (cost of stimulation and cost of tapping 
labor). However, the costs of tapping labor were much lower in the production systems that minimize the cost of latex harvesting. Hence the lower operating costs induced by these low frequency tapping systems.

It is clearly found that in a normal context of tapping labor availability, the use of production systems to minimize the cost of latex harvesting results in farmer's profit margins losses when the compensation of the tapper is performance-based. This could be explained by the fact that production losses, and hence revenue, are too high to be compensated by the tapping labor savings of 25, 37.5 and $50 \%$ caused by tapping in $\mathrm{d} 4$, d5 and $\mathrm{d} 6$ (Soumahin, 2010 ; Soumahin et al, 2010). And also the results of this study showed that, when the tapper payment was workday-based, the profit margins of low tapping frequency production systems in clone IRCA 130 and the tapping in $\mathrm{d} 4$ and $\mathrm{d} 5$ in clone GT 1 were higher than those of the control. Indeed, the payment of tapping labor per workday further reduced operating costs, which made production systems to minimize the costs of latex harvesting have profit margins higher than the conventional tapping. The profit margins of tapping in d6 in GT 1 and those of low tapping frequency in PB 217 lower than those of the conventional tapping could be explained by the fact that revenue losses due to rubber yield losses were too high to be compensated by the low cost of tapping labor (Soumahin, 2010 ; Soumahin et al, 2010).

In a context of tapping labor shortage, production systems to minimize the cost of latex harvesting (d4, d5 and d6) and help increase the tapped areas (4, 5 and 6 ha instead of 3 ha for tapping in d3), would induce higher farmer's profit margins, regardless of the clone and the tapper payment method.

Further, this investigation revealed that the tapper's annual income increased in production systems to minimize the cost of latex harvesting, especially when the latter is paid according to performance. Indeed, production systems to minimize the cost of latex harvesting, by improving the daily productivity of the tapper, improve worker's income. However, the income of the tapper paid according to workday remained unchanged insofar as the number of working days remained the same $(6 \mathrm{~d} / 7)$.

\section{Conclusion}

The study of production systems to minimize the cost of latex harvesting has shown that these systems can be adopted to solve the problem of tapping labor availability.

Indeed, these production systems, although resulting in rubber yield losses ranging from 1 to $6 \%$, from 6 to $24 \%$ and from 8 to $37 \%$ respectively in clones IRCA 130, GT 1 and PB 217, significantly improve the yield per tree and per tapping as well as the tapper's productivity (from 20 to 46\%). There is an advantage of favoring better vegetative growth of the trees while maintaining a low rate of tapping panel dryness (less than 7\%) by adapting 
this low tapping frequency systems. Production systems to minimize the cost of latex harvesting, while increasing the cost of the stimulant, significantly reduce the cost of tapping labor (by 1 to 50\%) and thus the operating expenses (by 2 to 47\%). Moreover, in the context of tapper shortage, they help increase the farmer's profit margin by $26 \%$ to $88 \%$ and $31 \%$ to $113 \%$ when the tapper's compensation is performance-based and workday-based respectively. Finally, production systems to minimize the cost of latex harvesting help increase the tapper's income from 26 to $89 \%$ irrespective of performance-based and workday-based systems. Production systems to minimize the cost of latex harvesting appear to be promising systems in the context of skilled tapper shortage in order to increase tapped areas and maintain rubber yield at a high level. They proved to be important especially as they help extend the economic life of rubber tree plantations and increase the value of the profession of tapper whose income is increased with adopting the low tapping frequency systems.

\section{References:}

1. Atsin GJO, Soumahin EF, Kouakou TH, Elabo AEA, Okoma KM and Obouayeba S., 2016. Agronomic Potential of Some Rubber Tree Clones (Hevea brasiliensis) of the Fast Metabolic Activity Class in the Absence of Hormonal Stimulation in South-western of Côte d'Ivoire. Am. J. Exp. Agri., 13 (4) pp. 1-13.

2. Bouychou J. G., 1962. La saignée de l'hévéa, manuel du planteur d'hévéa, Soc. Techn. Contin., Paris, 50 p.

3. Brou Y. T., 2005. Climat, mutations socio-économiques et paysages en Côte d'Ivoire. Mémoire de synthèse des activités scientifiques présenté en vue de l'obtention de l'habilitation à diriger des recherches. Université des Sciences et Technologies de Lille, 213 p.

4. Chapuset T. H., 2001. Description des clones étudiés à grande échelle. Rapport CNRA-HEVEA n ${ }^{\circ} 01 / 01,36$ p.

5. Chrestin H., 1984. Le compartiment vacuo-lysosomal (les lutoïdes) du latex d'Hevea brasiliensis, son rôle dans le maintien de l'homéostasie et dans les processus de sénescence des cellules laticifères. Thèse Doct. Etat Sci. Nat., Université Sci. Tech. Languedoc, Montpellier, France, $575 \mathrm{p}$.

6. Chrestin H., 1985. La stimulation à l'Ethrel de l'hévéa; jusqu'où ne pas aller trop loin. Caoutch. Plast., 647/648. 75-78.

7. Compagnon P., 1986. Le caoutchouc naturel. Coste R. ed., G.P. Maisonneuve et Larose, Paris, 17, 18, 19, 75, 76, 77, 219, 220.

8. De Fây E., 1981. Histophysiologie comparée des écorces saines et pathologiques (maladies des encoches sèches) d'Hevea brasiliensis. Thèse de doctorat $3 \mathrm{e}$ cycle. Université des Sciences et Techniques du Languedoc, Montpellier, France, 66 p. 
9. Gohet E., Prévôt J. C., Eschbach J. M., Clément A. and Jacob J.L., 1996. Clone, croissance et stimulation, facteurs de la production de latex. Plantations, recherche, développement, 3 (1) pp. $30-38$.

10. Kely J. Z., Oboayeba S. and Zehi B., 1992. Influence de quelques systèmes vivriers sur le comportement de jeunes hévéas en basse Côte d'Ivoire. Systèmes agricoles en Afrique, 2(1). 41-48.

11. Obouayeba S., Boa D., Ake S. and Lacrote R., 2002. Influence of age and girth at opening on growth and productivity of Hevea. Indiana Journal of Natural Rubber Research, 15 (1) pp. 66-71.

12. Obouayeba S. and Boa D., 1993. Fréquence et repos annuel de saignée d'Hevea brasiliensis, clone PB 235, dans le sud-est de la Côte d'Ivoire. Cahiers Agricultures, 2 (6), pp. 387 - 393.

13. Rodrigo V. H. L., Wickramarathna N. A. A. D. and Widanapthirana R. D., 2003. Present status of labour avaibility for latex exploitation and possible adoption of low frequency tapping in the plantation sector of Sri Lanka. In: Proceedings of the International Workshop on Exploitation technology, India, pp. 115-126.

14. Soumahin E. F., Obouayeba S. and Anno A. P., 2009. Low frequency tapping with hormonal stimulation on Hevea brasiliensis clone PB 217 reduces tapping manpower requirement. Journal of plant and animal sciences, 2 : pp.109-117.

15. Soumahin E. F., Obouayeba S., Dick K. E., Dogbo D. O. and Anno A. P., 2010. Low intensity tapping systems applied to clone PR 107 of Hevea brasiliensis (Muell. Arg.) : Results of 21 years of exploitation in South-eastern Côte d'Ivoire. African Journal of Plant Science, Vol. 4(5), pp. 145-153.

16. Soumahin E. F., 2010. Optimisation des systèmes d'exploitation en hévéaculture par la réduction des intensités de saignées. Thèse de Doctorat, Université de Cocody-Abidjan, Côte d'Ivoire, 189 p.

17. Soumahin E.F., Elabo A.A.E., Okoma K.M., Atsin G.J.O., Dick A.E. and Obouayeba S., 2014. Yield response of low frequency upward tapping by increase the tapping length cut in Hevea brasiliensis (clone GT 1) in south-eastern Côte d'Ivoire. Rubber Science 27(2) 87-95 pp.

18. Templeton J. K., 1969. Partition of assimilates. Journal of Rubber Research Institute of Malaysia, 21: pp.259-273.

19. Van De Sype H., 1984. The dry cut syndroms of Hevea brasiliensis, evolution, agronomical and physiological aspects. C. R. Coll. Physiol. Amél. Hévéa., Ed., IRCA-CIRAD, Montpellier, France, pp. 249 - 271. 